\title{
Dynamics of Establishment of the Enterprises and the Entrepreneurship in Romania
}

\author{
By Petrică Sorin Angheluțắn , Mihaela Diana Negescu Oancea², Amelia Diaconu', \\ Cristina Dima ${ }^{4}$
}

\begin{abstract}
The prosperity of a society is influenced by the existence of an industrial base. The stronger the industrial base, the more the society is considered to be more prosperous. A high degree of enterprises competitiveness leads to jobs that favor business development. The entrepreneurial spirit contributes to the development of businesses. For Romania, the article presents the evolution of the indicators regarding the degree of establishment of the newly created active companies. Also, the dynamics of the activity of newly created active enterprises in Romania is addressed. The level of education and the age of the founder differ depending on the activity sector of the newly created active enterprise. From the evolution analyzed, it can be concluded that, in Romania, the profile of the investor is represented by an individual under the age of 40, a high school graduate or who has university studies. For Romania, in recent years, the number of newly created active enterprises has decreased in the trade sector. Also, the sector with the highest dynamics in terms of setting up and closing companies, is the agriculture, forestry and fisheries sector. These aspects are important for the economy, but also for the studies of the analysis of the training needs. In the process of generating new sources of economic growth, a relevant contribution is provided by the degree to which the entrepreneurial culture is promoted.
\end{abstract}

Keywords: entrepreneurship, sustainable development, Romania

\section{Introduction}

The educational field, but also the economic and social fields, are influenced by globalization. Within the activities carried out in a community, the intervention of community members who have a high level of competence is much more active. The interest of the members of a community for acquiring new skills or for updating their skills, leads to development gaps between regions.

Automation helps to reorganize jobs. The skills and abilities that people have are influenced by the changes that occur in the labor market. The increase in the level of skills is given by the increased complexity of the jobs.

The premises of the implementation of new businesses are offered by the technological progress. It influences the labor market. Thus, entrepreneurship plays an important role in developed economies. Economic growth can be based on entrepreneurship. Opportunities in the labor market generate new jobs. At the same time, technological progress leads to increased labor productivity.

The decrease of prices in a field is also influenced by the existence in that field of activity 
of a large number of companies. Thus, the importance of new companies in creating new jobs increases. The quality of the products manufactured under these conditions increases. The use of the latest technologies in the production processes contributes to the increase of the quality of the products.

Some of the contributions that small and medium-sized enterprises can make to sustainable economic development are the creation of new jobs and the reduction of unemployment. The entrepreneur who lays the foundations of a new enterprise, through an innovative and creative spirit, can contribute to the success of the respective business. Capital investment, as well as the management of the company, represent responsibilities that an entrepreneur assumes.

The pedagogical methods that the teachers apply can help motivate the choice of one career to the detriment of another. Also important are the teaching methods used by teachers, as well as their level of preparation (Baneviciute and Kudinoviene, 2015). The transition to the labor market is facilitated by high-level training of graduates. Thus, students' choices are influenced by the social environment from which they come (Hällsten and Thaning, 2018).

\section{Literature Review}

Economic development in local communities can be influenced by the form and size of entrepreneurial activities (Jianu et al., 2019). Publicizing positive examples can be the basis for the development of entrepreneurial activities (Bodislav et al., 2019). Also, the educational programs developed locally contribute to the improvement of the skills of the local entrepreneurs (Burlacu, 2011). Interaction with other entrepreneurs and other companies allows the acquisition and growth of the experience. These interactions involve both risks and uncertainties (Bran et al., 2018). Thus, entrepreneurs are in a position to make decisions regarding both the economic and social aspects (Costache et al., 2015). Decreased performance in the workplace is due to possible dissatisfaction manifested in the workplace. This manifestation negatively influences the economic situation (Ionita et al., 2009).

Information technology contributes to educational mobility, which creates high mobility of the workforce (Burlacu et al., 2019). Thus, graduates will acquire higher quality skills (EC, 2015). Workplaces are influenced by automation. The number of jobs will decrease with preference in those sectors that are closely related to the technological processes. These changes will also contribute to the modification of the current models of employment (CEDEFOP, 2018a).

Productivity has also increased as a result of the creation of new jobs. Also, the increase of the sustainable use of resources was achieved with the help of new production technologies and investments in research and innovation (EC, 2019). The creation of new jobs and the economic growth is influenced by the activities of the companies that are oriented towards the local or regional markets. The implementation of new technologies can be achieved through technological exchange and cooperation between different companies (Androniceanu et al., 2017). Participation in these partnerships of universities adds value to these activities (Angheluta et al., 2019).

There have been several transformations in universities. These have changed the basis of 
the relationship between the relationship between universities and society. International competition is transformed internally into the contribution they make to society and the economic environment (Bran et al., 2018). The orientation towards certain disciplines is influenced by the chosen study route. Thus, jobs can be changed more easily if graduates have transferable skills and knowledge. For this reason, there is no longer a close link between certain disciplines and new occupations in the labor market. It is found that, based on the aging of specialized professional knowledge and the decrease of the focus on specific skills, the focus on general skills has increased (Puhakka et al., 2010).

The adaptation of the education and training systems is necessary due to the changing needs of the labor market, but also of the social needs (Costache et al., 2015). Continuous training in business can help to adapt to the new demands of the labor market. At the enterprise level, a good managerial management is based on a good knowledge of the trends of the labor market (Rădulescu et al., 2018). It must also take into account the labor force needs (CEDEFOP, 2017).

Partnerships between businesses and educational institutions contribute to improving the employability (Burlacu \& Jiroveanu, 2011). The acquisition of skills is greatly facilitated through practical training in the workplace (OECD, 2017). An important aspect is given by the anticipation of the competencies needed in companies (ETF, 2018).

\section{Methodology of Research}

The article presents the evolution of the indicators regarding the degree of establishment of the newly created active enterprises in Romania, as well as the dynamics of the activity of the newly created active enterprises in Romania. The influence of the level of education and the age of the founder in setting up new companies is analyzed. Also, the dynamics of setting up new companies according to the sector of activity of the enterprise are tracked.

At the same time, comparative analyzes of the information regarding the newly created active companies are presented according to the education level of the founders.

\section{Results and Discussions}

The economic activity of enterprises at local or regional level can be the basis of regional development. Depending on the training level of the founder, the evolution of the distribution of newly created active enterprises in Romania is presented in Figure 1 $(\%)$. 


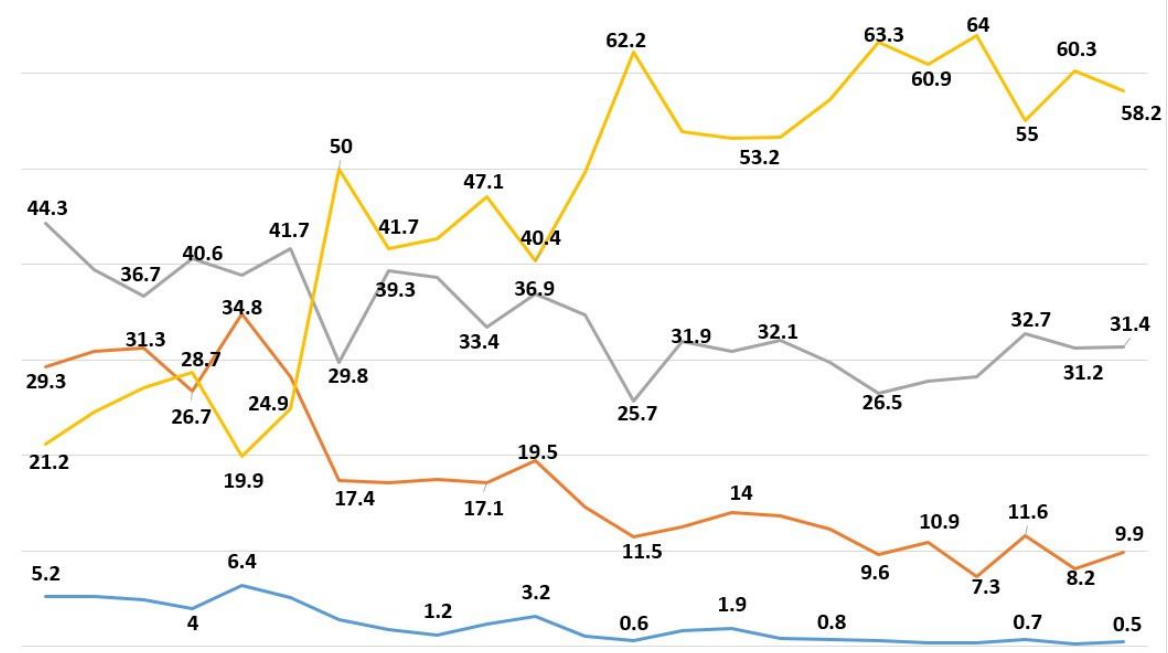

19951996199719981999200020012002200320042005200620072008200920102011201220132014201520162017

$$
\text { —Primary - Vocational - Secondary - High school or university }
$$

Figure 1 - Distribution of newly created active enterprises, according to the founder's training level, 1995-2017 (\%) Source: processing according to data published by National Institute of Statistics, 2020

From the data presented, we find that the weights are lower for the situation in which the founder has a lower level of training. In 1995, the share of people with primary education from the total of newly created active enterprises was 5.2\%. In 2017, the values of this indicator went down to $0.5 \%$. Similarly, for people with vocational education, a decrease in values is observed. For these people, after a relative increase (in the period 1995-1999) there is a decrease of values up to $9.9 \%$ (in 2017). Also, it can be noticed that even in the case of people with the level of training in the secondary category, the share of newly created active enterprises decreased. For this level, in 1995 the share of people with the secondary education level was $44.3 \%$, and in 2017 the values had decreased to $31.4 \%$. However, for the period 1995-2017, there is an increase in the share of newly created active enterprises for which the educational background of founder / manager is in the high school or university category. If in 1995, this indicator had a value of $21.2 \%$, in 2017 the share of newly created active enterprises was $58.2 \%$.

Table 1 presents the comparative situation of the share of newly created active enterprises according to the educational background of founder / manager, for 2001 and for $2017(\%)$.

From the data presented in the previous table, it can be seen that the highest values correspond to the high school or university category. The Bucharest - Ilfov region is the region with the highest values for this category of training, both in 2001 and in 2017. Also, compared to 2011, it is observed that in 2017 for the high school or university category the values have raised for all regions. The highest growths were recorded in the regions: Bucharest - Ilfov, Center, North - West, West. 
Table 1 - Comparative situation of the weight of newly created active companies according to educational background of founder, 2010-2017, (\%)

\begin{tabular}{|c|c|c|c|c|c|c|c|c|}
\hline \multirow[b]{2}{*}{ Development regions } & \multicolumn{4}{|c|}{2001} & \multicolumn{4}{|c|}{2017} \\
\hline & ב己 & 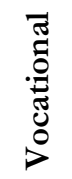 & 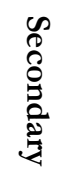 & 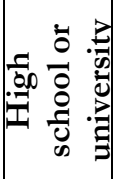 & : & 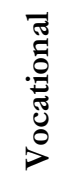 & 完 & 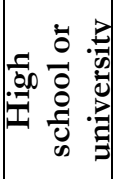 \\
\hline North - East & 1.3 & 28.9 & 22.8 & 47.1 & 0.3 & 14.5 & 30.5 & 54.7 \\
\hline South - Muntenia & 0 & 29.6 & 36.7 & 33.7 & 2 & 13.9 & 40.4 & 43.7 \\
\hline South - West Oltenia & 5.2 & 23.4 & 34.3 & 37.1 & 0.7 & 9.1 & 40.6 & 49.6 \\
\hline North - West & 5 & 21.6 & 33.6 & 39.8 & 0.2 & 7.8 & 27.6 & 64.4 \\
\hline West & 3.3 & 26.8 & 42.2 & 27.7 & 0 & 8.8 & 36.5 & 54.7 \\
\hline South - East & 8.1 & 18.5 & 32.7 & 40.7 & 0 & 7.4 & 42.5 & 50.1 \\
\hline Center & 2.6 & 25.8 & 36.1 & 35.5 & 0 & 11.1 & 23.2 & 65.7 \\
\hline Bucharest - Ilfov & 2.7 & 20.7 & 16.4 & 60.2 & 0.9 & 5.1 & 30.5 & 84 \\
\hline
\end{tabular}

Source: processing according to data published by National Institute of Statistics, 2020

Corresponding to the year 2017, for the Bucharest - Ilfov Region, figure 2 shows the distribution of newly created active enterprises according to educational background of founder / manager $(\%)$.

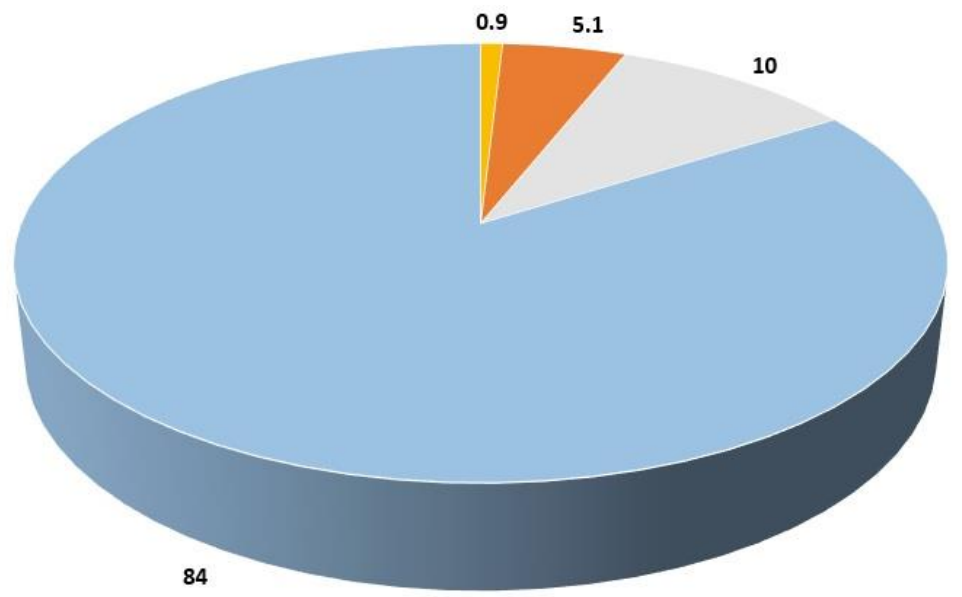

Figure 2 - Distribution of newly created active enterprises according to educational background of founder, 2017 (\%)

Source: processing according to data published by National Institute of Statistics, 2020

From the previous figure, it is observed that an overwhelmingly high share of newly created active enterprises corresponds to a training of the high school or university level founder $(84 \%)$. 
One of the main purposes for which there is a high interest for university-level studies is given by the increased employment prospects. The chances of graduates to take up a job quickly are higher if they have an education closer to the labor market. For some graduates, employment may be a difficult task if education is not related to an occupation. In recent years, the degree of employment is a predominant factor of the university systems. The level of graduates' skills and knowledge influences the degree of employment. The desired situations involve having transferable skills and competences between several occupations. Therefore, although graduates have relied more on professional skills when occupying a job, general skills are gaining more ground (Puhakka et al., 2010).

The correlation of graduates' skills with the needs of the labor market leads to the development of a skilled workforce, easily adaptable to changes and which can anticipate the skills needed.

For the year 2017, the distribution of newly created active companies according to the age of the founder / manager, is presented in the following figure.

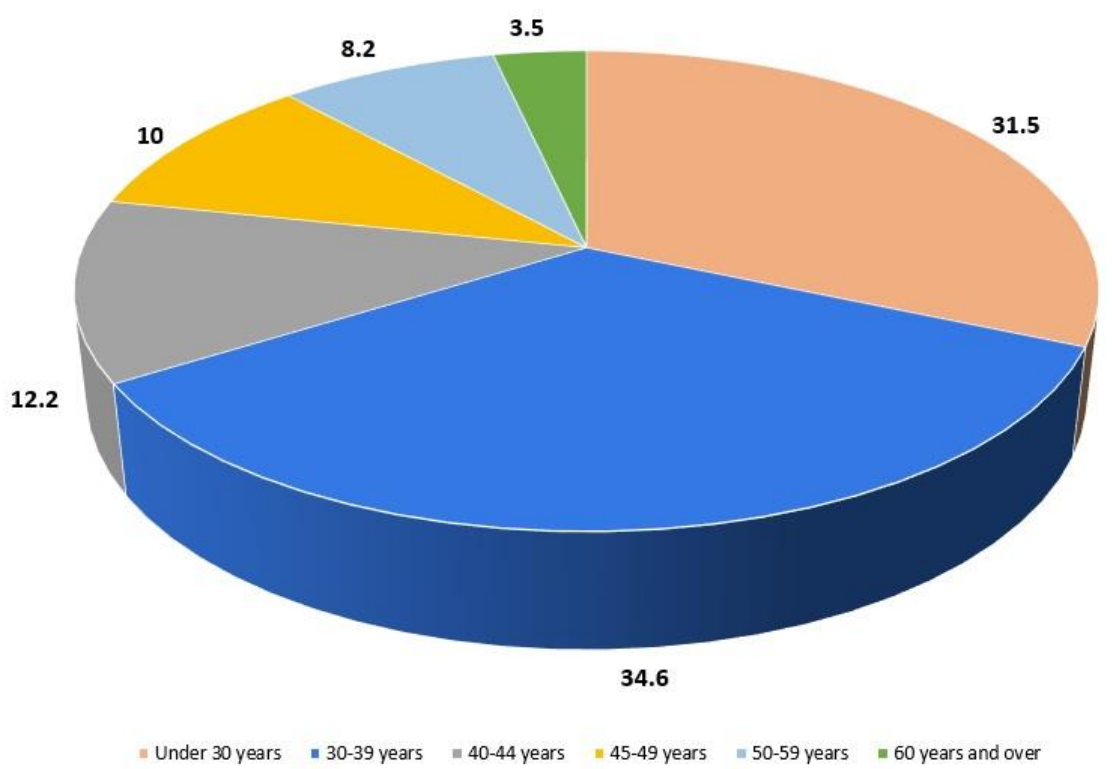

Figure 3 - Distribution of newly created active companies by age of founder, 2017 (\%)

Source: processing according to data published by National Institute of Statistics, 2020

It is found that, in 2017, the age of the founder / manager of the newly created active companies was mainly under 40 years. Thus, for the age group under 30 years, the weight is $31.5 \%$, and for the age group 30-39 years the weight is $34.6 \%$. The lowest weight is given by the age group over 60 years $(3.5 \%)$.

For 1995 and 2017, figures 4 and 5 show the distribution of newly created active enterprises, according to the sector of activity. 


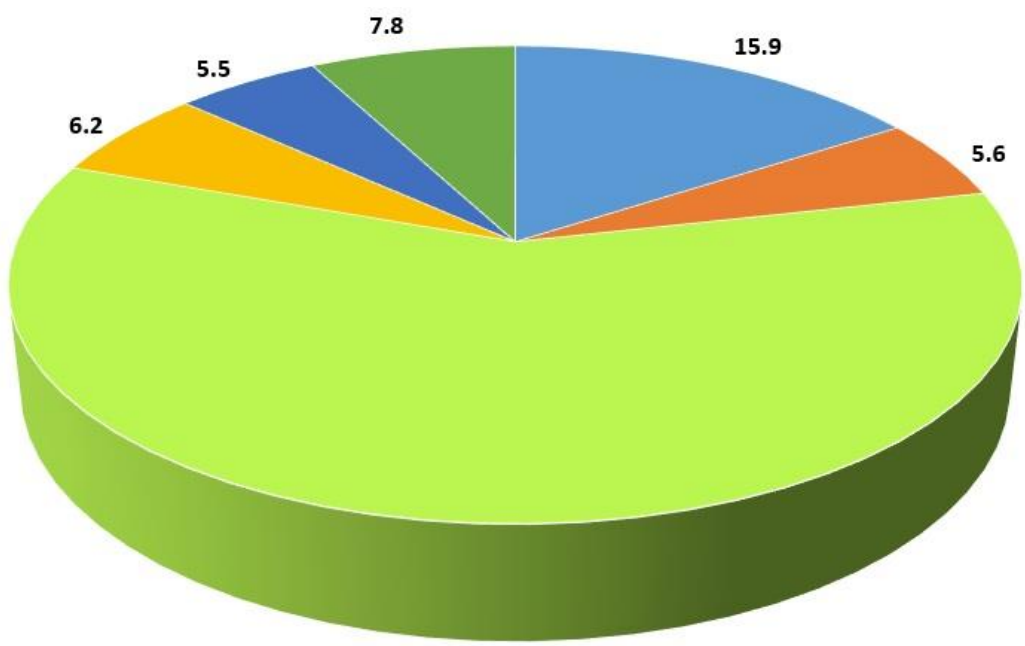

59

- Industry $=$ Constructions "Trade $=$ Hotels and restaurant $=$ Transportation $=$ Other services

Figure 4 - Distribution of newly created active companies, by activity sectors, 1995 (\%)

Source: processing according to data published by National Institute of Statistics, 2020

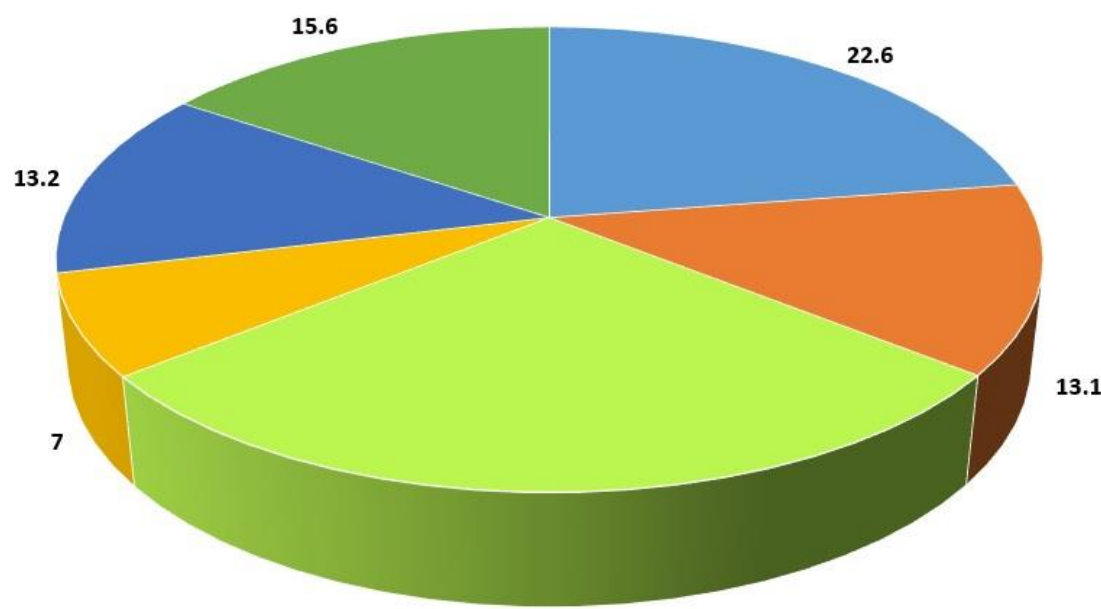

28.5

- Industry = Constructions "Trade " Hotels and restaurant " Transportation = Other services

Figure 5 - Distribution of newly created active companies, by activity sectors, 2017 (\%)

Source: processing according to data published by National Institute of Statistics, 2020

It can be seen that the sectors of industry, construction, transport and other services respectively increased by about $7 \%$ of the share of newly created active enterprises. Thus, for the industry sector, the values of this indicator increased from $15.9 \%$ (1995) to $22.6 \%$, (2017). For the construction sector, the growth was from $5.6 \%$ to $13.1 \%$, and for 
the transport sector, the growth was from $5.5 \%$ to $13.2 \%$. The only sector for which there have been decreases is the trade sector. Here, the decrease was $30.5 \%$, from $59 \%$ to $28.5 \%$.

The following figure shows the evolution of the number of active companies, for the period 2008-2017.

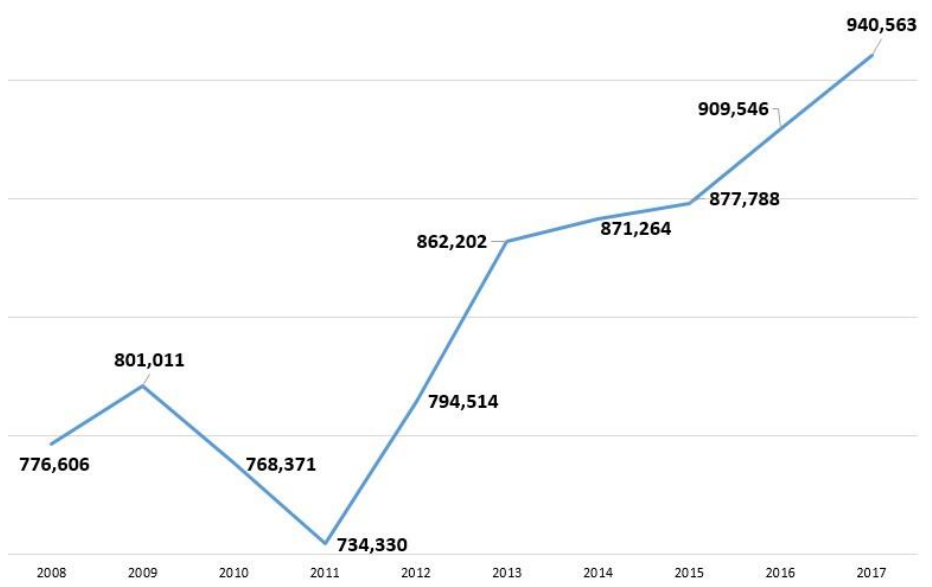

Figure 6 - Evolution of the number of active companies, 2008-2017

Source: processing according to data published by National Institute of Statistics, 2020

It is noted that the period 2009-2011 is characterized by a decrease in the number of active enterprises. After 2011, the number of active enterprises increases every year. Thus, if in 2011 there were 734330 active companies, in 2017 their number was 940563. Compared to 2008, in 2017, the sector with the largest growth was the agriculture, forestry and fisheries sector. The evolution of the number of active enterprises for the agriculture, forestry and fisheries sector is shown in the following figure.

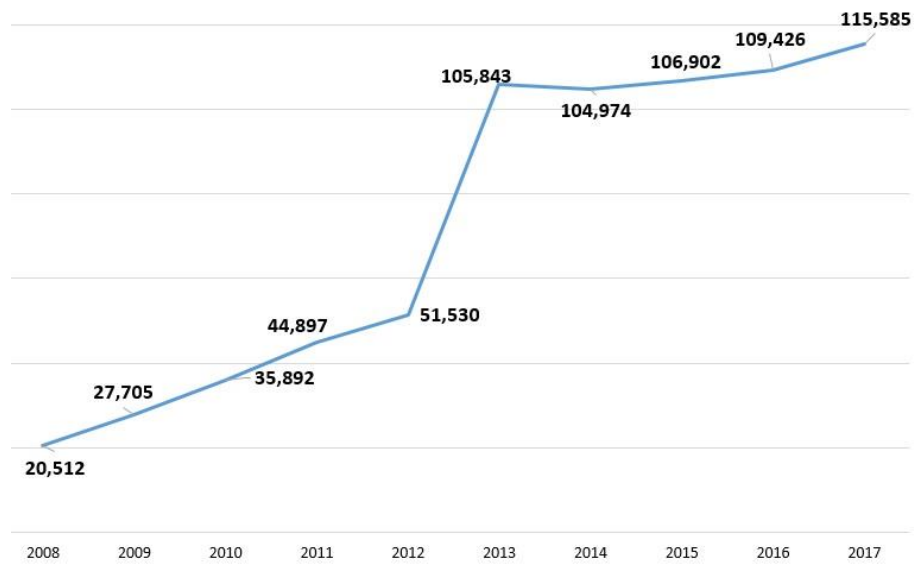

Figure 7 - Evolution of the number of active enterprises for the agriculture, forestry and fisheries sector, 2008-2017 Source: processing according to data published by National Institute of Statistics, 2020 
For the period analyzed (2008-2017), the number of active enterprises in the agriculture, forestry and fisheries sector has been steadily increasing. Thus, compared to 2008, in 2017, there were 95073 more active companies.

The following figure shows the evolution of the number of companies set up in 20082017.

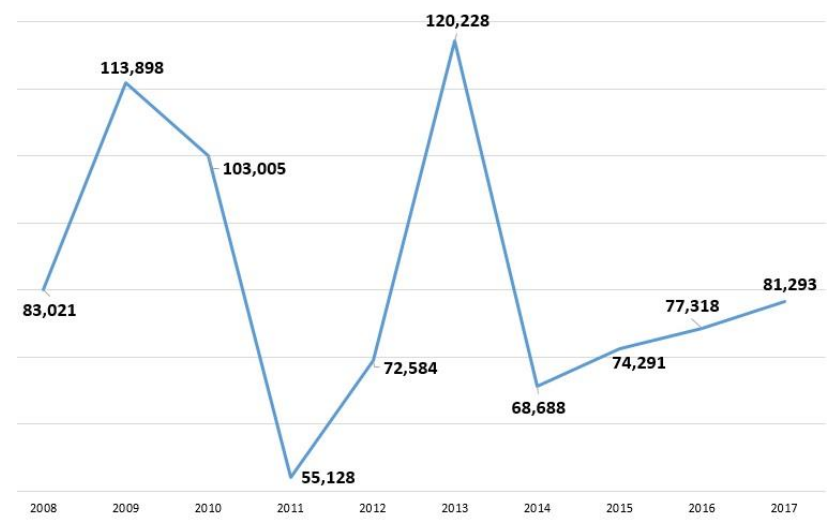

Figure 8 - Evolution of the number of companies canceled, 2008-2017

Source: processing according to data published by National Institute of Statistics, 2020

It can be seen that for the periods 2009-2011 and 2013-2014, respectively, the number of companies canceled decreased. Also, in the periods 2008-2009, 2011-2013 and 20142017, respectively, the number of companies canceled increased. Thus, in 2017, the number of companies canceled was similar to that of 2008 (81293 companies compared to 83021 companies).

In 2017, as in fact, in 2008, most of the disbanded companies come from the trade sector. The evolution of the number of companies set up in the trade sector, for the period 2008-2017, is shown in the following figure.

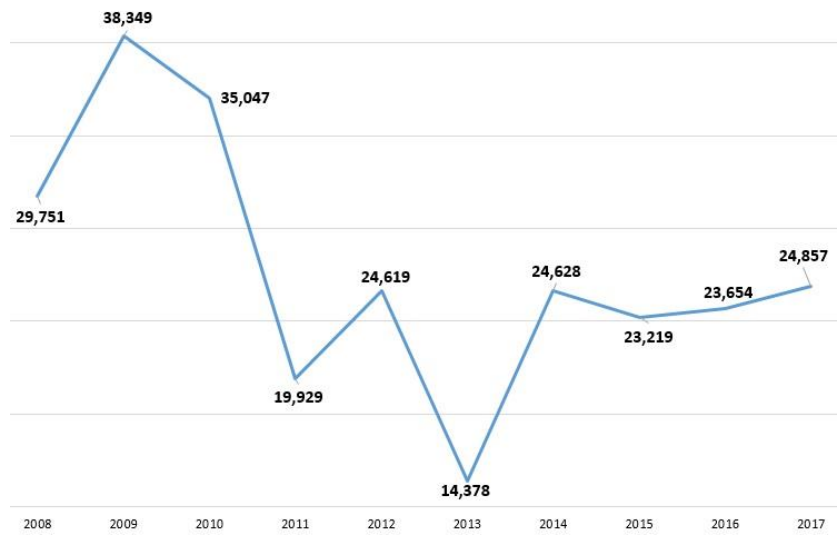

Figure 9 - Evolution of the number of companies set up in the trade sector, 2008-2017

Source: processing according to data published by National Institute of Statistics, 2020 
It can be seen that for the periods 2009-2011, 2012-2013 and 2014-2015, respectively, the number of companies canceled decreased. Also, in the periods 2008-2009, 20112012, 2013-2014 and 2015-2017, respectively, the number of canceled companies increased. However, in 2017, compared to 2008, fewer companies were discontinued (24857 companies compared to 29751 companies).

\section{Conclusions}

By promoting a positive image, entrepreneurs have the opportunity to develop their activities better. The importance of the education system is increasing. Participation in specialized programs to promote entrepreneurship can contribute to the accumulation of knowledge regarding business development.

The importance given to the productive sector based on the use of local potential and resources is increasing.

The analysis presented demonstrates the importance of the educational background of founder/ manager. Thus, for people in the high school or university category, there is an increase in the share of newly created active enterprises. The Bucharest - Ilfov region is the region in which the founders with a high level of education in the high school or university category have the highest share of newly created active enterprises. At the same time, based on the data presented, an investor profile in Romania may be available. He is up to 40 years old, a high school graduate, respectively of university studies. The number of active enterprises has increased, and the agriculture, forestry and fisheries sector is the fastest growing sector. The sector in which most enterprises were abolished is the trade sector. For this sector the number of newly created active enterprises has decreased. The conclusions of these analyzes are relevant to analyze the needs of education and training.

It is noted that the possession of relevant skills is becoming more and more important, and the number of platforms that have such skills will be increasing. The new economic models will make distances no longer barriers and mobility will be an advantage (UNESCO, 2018).

Strategies involving educational measures and measures related to employment can lead to maintaining and increasing productivity in enterprises. The basis of these strategies should be made up of relevant information coming from the labor market (ETF, 2016). Also, participating in the education and training programs of the employees of a company leads to maintaining a balance between the competences of the employees and the qualification needs of the company (CEDEFOP, 2018b).

\section{References}

Androniceanu, A., Burlacu, S., Drăgulănescu, I. V., \& Nicolae, E. E. (2017, May). New trends of businesses digitalization in Romania and the behaviour young consumers. In BASIQ International Conference: New Trends in Sustainable Business and Consumption, Graz (Vol. 31, pp. 27-35).

Angheluta, S. P., Burlacu, S., Diaconu, A., \& Curea, C. S. (2019). The Energy from Renewable Sources in the European Union: Achieving the Goals. European Journal of Sustainable Development, 8(5), 57.

Baneviciute, B., Kudinoviene, J., (2015). Arts Teacher Education In Lithuania: Aspects Of Postgraduate Arts Education Research, Procedia - Social and Behavioral Sciences, 191, 302 - 307 
Bodislav, A. D., Rădulescu, C. V., Moise, D., \& Burlacu, S. (2019). Environmental Policy in the Romanian Public Sector. The Bucharest University of Economic Studies Publishing House, 312.

Burlacu, S. (2011). The role of NGOS in awareness of the public private partnership in the social economy in Romania. In Proceedings of Administration and Public Management International Conference (Vol. 7, No. 1, pp. 118-127). Research Centre in Public Administration and Public Services, Bucharest, Romania.

Burlacu, S., \& Jiroveanu, D. C. (2011). The develope of software solution for supply chain management. Revista de Management Comparat International/Review of International Comparative Management, 12(6), 140-145.

Cedefop (2017). Skills Anticipation: Looking to the Future

Cedefop (2018a). Can work and technology go hand-in-hand?

Cedefop (2018b). From long-term unemployment to a matching job: the role of vocational training in sustainable return to work. Luxembourg: Publications Office

Costache, G., Marinas, C. V., Igret, R., \& Burlacu, S. (2015). Internship in the HR department-organizational and individual perspectives. In Proceedings of the International Management Conference (Vol. 9, No. 1, pp. 359-370). Faculty of Management, Academy of Economic Studies, Bucharest, Romania.

European Commission (2019). Reflection Paper - Towards a Sustainable Europe by 2030

European Council (2015). 2015 Joint Report of the Council and the Commission on the implementation of the strategic framework for European cooperation in education and training (ET 2020) - New priorities for European cooperation in education and training

European Training Foundation (2018). Getting ready for the future

European Training Foundation/European Centre for the Development of Vocational Training/International Labour Office (2016). Developing Skills Foresigbts, Scenarios and Forecasts: Guide to Anticipating and Matching Skills and Jobs, Luxembourg: Publications Office of the European Union

Hällsten, M., Thaning, M., (2018) Multiple dimensions of social background and horizontal educational attainment in Sweden, Research in Social Stratification and Mobility 56, 40-52

Ionita, F., Ursacescu, M., \& Burlacu, S. (2009). Public services as poles of regional competitiveness in sustainable development. Revista de Management Comparat International/Review of International Comparative Management, 10(3), 552-565.

Ioniţă, F.; Burlacu, S. \& Gaidargi, A.(2009) Modern approaches of the management of alternative trade systems, Revista de Management Comparat International/Review of International Comparative Management,51, 473-480

Jianu, I., Dobre, I., Bodislav, D. A., Radulescu, C. V., \& Burlacu, S. (2019). The implications of institutional specificities on the income inequalities drivers in European Union. Economic Computation and Economic Cybernetics Studies and Research, 53(2), 59-76.

National Institute of Statistics, (2020), www.insse.ro

Organization for Economic Cooperation and Development (2017). Educational Opportunity for All: Overcoming Inequality throughout the Life Course, OECD Publishing, Paris

Puhakka, A., Rautopuro, J., Tuominen, V., (2010) Employability and Finnish University Graduates, European Educational Research Journal 9(1)

Rădulescu, C. V., Dobrea, R. C., \& Burlacu, S. (2018) The business management of distress situations. The 12th International Management Conference "Management Perspectives in the Digital Era" November 1st-2nd, 2018, Bucharest, Romania, 1, 741-747

UNESCO (2018). Global Education Monitoring Report 2019: Migration, Displacement and Education - Building Bridges, not $W$ alls. Paris, UNESCO 